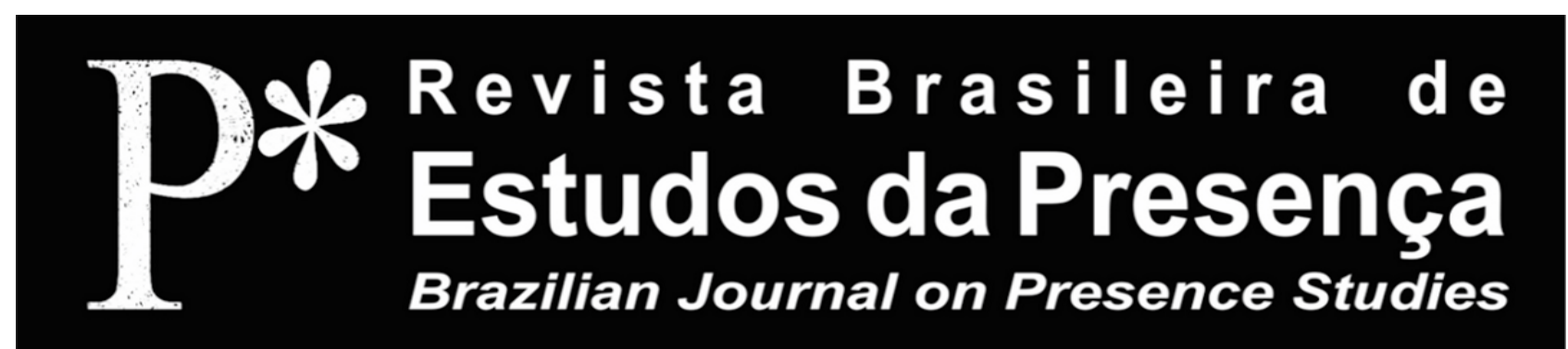

\title{
O balé por escrito: preceitos e regras de composição dos balés de corte na França do Antigo Regime (1581-1682)
}

Clara Rodrigues Couto

IFaculdade de Filosofia, Letras e Ciências Humanas da Universidade de São Paulo - FFLCH-USP, São Paulo/SP, Brasil

RESUMO - $O$ balé por escrito: preceitos e regras de composiçáo dos balés de corte na França do Antigo Regime (1581-1682) - O presente artigo busca compreender as formulaçóes teóricas que ao longo do século XVII sistematizaram o balé de corte como arte, termo entendido à época como um conjunto de preceitos e regras. Após um breve arrazoado sobre os primeiros manuais de dança produzidos na Europa moderna, analisamos os tratados, discursos e libretos que versavam sobre a composição de balés. A partir das obras de Beaujoyeulx, Saint-Hubert, Marolles, De Pure e Ménestrier, entre outros, seria possível compreender os princípios eruditos e os preceitos orientadores da prática de composiçāo desse espetáculo dançado na França do Antigo Regime, bem como a inserçáo da dança e do balé no domínio da produção escrita e da cultura letrada.

Palavras-chave: Balé de corte. Tratados de dança. Sociedade de corte. França. Antigo Regime. ABSTRACT - Ballet in writing: precepts and rules of composition for court ballets in France under the Ancien Régime (1581-1682) - This article seeks to understand the theoretical formulations that throughout the $17^{\text {th }}$ century systematized court ballet as an art, a term defined at the time as a set of precepts and rules. After a brief discussion about the first dance manuals produced in modern Europe, we analyze the treatises, discourses and librettos that addressed ballet composition. From the works of Beaujoyeulx, Saint-Hubert, Marolles, De Pure and Ménestrier, among others, it is possible to appreciate the erudite principles and precepts that guided the practice of ballet composition in France under the Ancien Régime, as well as the inclusion of dance and ballet in the domain of written production and literate culture.

Keywords: Court ballet. Dance treatises. Court society. France. Ancien Régime.

RÉSUMÉ - Le ballet par écrit : préceptes et règles de composition des ballets de cour en France sous l'Ancien Régime (1581-1682) - Cet article cherche à comprendre les formulations théoriques qui, tout au long du XVIIe siècle, ont systématisé le ballet de cour comme un art, terme compris à l'époque comme un ensemble de préceptes et de règles. Pour cela, nous avons récupéré les premiers manuels de danse écrits en Europe moderne pour ensuite analyser les traités, discours et livrets qui portaient sur la composition des ballets. A partir des œuvres de Beaujoyeulx, Saint-Hubert, Marolles, De Pure et Ménestrier, entre autres, il serait possible de comprendre les principes et préceptes qui ont guidé la pratique de composition du ballet en France sous l'Ancien Régime, ainsi que l'insertion de la danse et du ballet dans le domaine de la culture savante.

Mots-clés: Ballet de cour. Traités de danse. Société de cour. France. Ancien Régime. 
Conhecer as concepçóes e práticas da dança no âmbito da sociedade de corte na Europa Moderna, tanto a dança social quanto suas formas cênicas, é um importante elemento para a compreensão do balé de corte, entendido como elaboração cênica cuja composição se baseava na colaboração de várias artes: poesia, música, pintura, maquinaria e, sobretudo, a dança. O presente artigo buscará compreender as formulaçôes teóricas que, ao longo do século XVII, sistematizaram o balé de corte como arte, termo entendido à época como um conjunto de preceitos e regras. Longe de configurarem um corpus teórico abstrato e especulativo, tais formulaçóes tinham caráter eminentemente prático, na medida em que orientavam os mestres de balé na invenção, composição e conduçãa de um dos espetáculos mais recorrentes no cotidiano da corte francesa dos seiscentos. Pode-se dizer que essas regras e preceitos orientaram também a apreciação dos balés, uma vez que os mesmos nobres que tomavam parte na representação dos balés, ao lado de bailarinos de ofício, em outros momentos assistiam ao espetáculo como plateia.

No que tange à estrutura do artigo, iniciaremos delineando um breve inventário dos primeiros manuais de dança produzidos na Europa moderna, a partir do século $\mathrm{XV}$, no intuito de compreender em que medida essas práticas de escrita da/sobre a dança revelam sobre o processo de codificaçáo dos gestos e de constituição da dança aristocrática como uma arte bem regrada, nos termos da época. Em seguida, analisaremos a prática de escrita de tratados, discursos e libretos que versavam sobre a composição de balés, particularmente as obras de Beaujoyeulx, Saint-Hubert, Marolles, De Pure e Ménestrier, entre outros, como modelos orientadores desse fazer artístico.

A partir da leitura e análise desses tratados, libretos e discursos - documentos que testemunham da inserção da dança e do balé no domínio da produção escrita e da cultura letrada -, propomos uma sistematização dos princípios eruditos, das regras e preceitos orientadores das práticas de composição e representaçáo desse espetáculo dançado na França do século XVII. Sustentamos que o entendimento dos princípios e preceitos norteadores da composição dos balés de corte nos permite uma melhor compreensão e aprofundamento de análise dos espetáculos coreográficos e formas cênicas da dança daquela época, evitando, assim, leituras anacrônicas e juízos de valor que turvam uma compreensão histórica das concepçóes e práticas da dança. 
No desenvolvimento do artigo que se apresenta, partimos das abordagens metodológicas da História Cultural, sobretudo no que se refere à preocupaçáo com o caráter simbólico e com a história das práticas e representaçôes (Burke, 2008; Chartier, 1990) da dança. Uma vez que nosso recorte diz respeito a uma dança aristocrática desenvolvida na Europa moderna (especialmente na França dos séculos XVI e XVII), faz-se necessário entendê-la no contexto estruturante de uma sociedade de corte, segundo as formulaçóes de Norbert Elias. Para o sociólogo, as relaçôes sociais e políticas no Antigo Regime francês se dariam a partir de minuciosa codificação de gestos e condutas, bem como da cerimonializaçáo do comportamento, do status social e das atividades cotidianas (Elias, 2001).

Ainda em termos metodológicos, destacamos, no presente trabalho, o papel central da leitura e análise de fontes históricas escritas, especialmente tratados e libretos de balé, além de leitura e sistematizaçáo da bibliografia especializada sobre o tema. Cabe salientar que as reflexôes deste artigo se inserem no âmbito maior de nossa pesquisa de mestrado sobre a dança e os balés de corte como imagem prescritiva da harmonia cósmica e política na França entre 1610 e 1661 (Couto, 2015) ${ }^{1}$.

\section{A dança se torna uma "arte"}

É possível dizer que a dança sempre esteve presente nas mais diversas sociedades e culturas desde os tempos mais longínquos da história, seja como prática mais espontânea ou mais codificada. Há testemunhos disso em relatos escritos, imagens, tradiçôes orais e objetos materiais. Todas essas fontes históricas mostram-se indícios vagos e lacunares, dada a impossibilidade de registro direto e/ou material da dança em sua dimensão performática.

Relatos que mencionam a dança na vida cotidiana, em algum evento ou cerimônia pública/religiosa são frequentes em memórias, poemas, relaçôes de festas, bulas papais, determinações ou proibições eclesiásticas. Porém, na maior parte dos casos, limitam-se a evidenciar a presença dessa atividade na vida social ou, por vezes, incluem alguma descrição resumida.

Principalmente a partir do século XV, o tema da dança se tornará mais recorrente nas obras escritas da época, passando a assumir novos enfoques, novas formas e gêneros de escrita, em uma narrativa cada vez mais pormenorizada e sistemática. Isso ocorre justamente porque, a partir daquele mo- 
mento, a dança começará a ser pensada como arte na acepção moderna e humanista do termo, isto é, retomando as noçóes antigas de ars, artificium (latim) e téchné (grego) (Nicot, 1584, p. 53).

Nessa concepção, "[...] arte é principalmente um conjunto de preceitos, de regras, de invençóes e de experiências que, uma vez seguidos, permitem fazer coisas de maneira bem-sucedida, tornando-as úteis e agradáveis" (Furetière, 1690, n.p.). Entendia-se arte, portanto, como técnica sistematizada submetida a um método racional, cuja habilidade ou faculdade adquiria-se pelo estudo e pela prática desse conjunto de regras e preceitos específicos.

Percebe-se, nos idos do século XV, uma crescente tendência de metrificaçáo da dança, entendida como exercício e divertimento da nobreza nos ambientes palacianos europeus. Essa metrificaçáo correspondia à estruturação e regulamentação das formas, movimentos e gestos do corpo, passos e figuras espaciais em estreita relaçáo com as métricas poética e musical - essa última que se estruturava sobre as regras da polifonia e do contrapontismo ${ }^{3}$. Assim, perseguindo a beleza e a harmonia das formas, a dança passa por uma sistematização no intuito de equilibrar e refinar formalmente os movimentos corpo e figuras, adequando-os e vinculando-os à métrica musical e poética, elementos essenciais sobre os quais as danças eram compostas (McGowan, 2008).

É nesse momento, de crescente regulamentação da técnica e das formas que a dança começa a ser tratada sob novas abordagens, devido aos seus novos usos e aos gêneros de escrita, que também passam a constituir seu espaço a partir de então: coletâneas de partituras de músicas para dança, tratados e manuais de cunho prático e metódico voltados à sua instrução ou, ainda, discursos morais e filosóficos baseados nas autoridades clássicas. Esse aumento de documentos escritos voltados para o tema da dança nos informa, além da recorrência de sua prática, sobre como ela era concebida: sua natureza, suas formas e funçóes, sua importância e seu valor social.

A voga da dança pode ser percebida pela multiplicação de composiçóes e de coletâneas de músicas para dança desde inícios do século XVI, como o manuscrito Le livre des Basses danses de la Bibliothèque de Bourgogne 4 . Tais composiçóes musicais circulavam no ambiente das cortes, o que nos informa da crescente inserção da dança na vida cortesã. Segundo Margaret 
McGowan, Pierre Attaignant, impressor real de música, já publicava, desde 1529, coletâneas de basses danses, pavanas, galhardas e branles para conjunto de câmara, cravo e alaúde. Também foram numerosas as publicaçóes musicais de Adrian le Roy (entre 1551 e 1558) e os "[...] livros de danceries", publicados por Jean d'Estrées entre 1559 e 1564 (McGowan, 1978, p. 2930).

Mas são, principalmente, os tratados e manuais de dança, surgidos a partir de meados do século XV, que demonstram mais claramente a elaboraçáo de uma arte da dança. Isso se deve à peculiaridade da tratadística: gênero discursivo dedicado à sistematizaçáo racional e calculada de regras, preceitos e classificaçóes, no intuito de contemplar tanto os fundamentos teórico-filosóficos de determinada arte quanto suas aplicaçóes práticas e artifícios. Segundo Marina Nordera, nesse processo de "[...] redução da dança em arte" - ou seja, a sistematização de saberes teóricos e técnicos na forma escrita de manuais e tratados -, esses textos escritos passam a assumir valor de patrimônio e autoridade, dentro de uma tradiçáo predominantemente oral (Nordera, 2008).

A proliferação e a intensa circulaçáo desses documentos escritos a partir do final dos quinhentos tornam evidentes o valor e a necessidade de aprendizado dessa arte nas cortes europeias. Além disso, ali se encontram preciosas informaçóes técnicas e formais relativas aos passos, gestos e movimentos, às regras de boa execuçáo e postura, às características de cada tipo de dança, bem como às especificidades da maneira de dançar em diferentes regiôes e cortes. Tais informaçôes aparecem sob a forma de descriçóes textuais, gravuras, partituras e tablaturas musicais.

\section{Uma dança por escrito: os primeiros tratados e manuais}

As primeiras obras escritas como manuais de dança de que se tem registro na Europa ocidental datam do quattrocento e aparecem na Península Itálica (Cf. Nordera, 2008 e 2017). Domenico da Piacenza, reconhecido mestre de dança em Ferrara, teria escrito seu De arte saltandi et choreas ducendi $i^{5}$ por volta de 1425. Do mestre judeu Guglielmo Ebreo (ou Giovanni Ambrosio, seu nome cristão), conservam-se algumas versóes de seu manuscrito De pratica seu arte tripudii vulgare opusculum ${ }^{6}(1463 ; 1471-1474)$ e de Antonio Cornazzano, o manuscrito Libro dell'arte del danzare (c. 1455- 
1465). Na Península Ibérica, um manuscrito anônimo datado por volta de 1496 é conservado na cidade catalá de Cervera $^{8}$ (Lecomte, 2014, p. 23). Esses tratados contêm regras de execução dos passos e descriçôes de danças sociais diversas, além de informaçôes sobre danças de caráter um pouco mais dramático denominadas balli.

As regras de dança conquistam o mundo da tipografia e o manual de Michel de Toulouze, L'art et instruction de bien dancer', aparece como a primeira obra impressa do gênero, por volta de $1496 \mathrm{em}$ Paris, que se conserva até hoje. $\mathrm{O}$ poeta provençal Antoine Arena publicou seu tratado em 1528, em Lyon, dedicado às basses danses e branles ${ }^{10}$, onde pela primeira vez aparecem informaçóes sobre o comportamento no baile na França de sua época (Lecomte, 2014, p. 40-41). Sucessivamente, uma nova leva de manuais e tratados impressos aparece a partir de fins do século XVI. Neles, sáo introduzidas novas regras e invençôes de dança, novos elementos e recursos de instrução da dança (na prática escrita), ademais de informaçóes para o estudo das técnicas, corporalidade e formas cênico-coreográficas da época.

Publicado em Veneza, Il Ballarino ${ }^{11}$ (1581), de Fabrizio Caroso, apresenta, em sua primeira parte, os nomes de diversos passos e movimentos, seguidos das regras e instruçóes para sua execução, e na segunda parte, apresenta diversas composiçóes de danças e balli dedicadas a diversas damas da nobreza. O manual apresenta gravuras de posiçôes e gestos, além de sugerir a associação dos passos de dança às partituras musicais, no intuito de evidenciar o ritmo e cadência dos movimentos. Em 1600 Caroso publica seu Nobilità di Dame ${ }^{12}$, uma atualização corrigida e ampliada do primeiro tratado, acrescido de passos, danças e mais instruçóes voltadas especialmente ao gestual e ao comportamento das mulheres.

Em L'Orchésographie (1589) ${ }^{13}$, tratado em forma de diálogo publicado em Langres e atribuído a Thoinot Arbeau, reforçam-se os princípios teóricos de aproximação entre as artes: o ensino do "[...] honesto exercício da dança” é estreitamente associado à música, o que fica evidente nas explicaçôes dos passos sempre relacionados à melodia na partitura musical. Arbeau institui cinco posiçôes de pés, que servirâo como base para a invençấo de passos em diversas danças, e compara o dançarino a um orador: ao dar lugar de importância à mímica, o autor defende o caráter eloquente da dança como retórica muda (Arbeau, 1589, p. 5). Segundo McGowan, o tratado de 
Arbeau permite verificar as relaçóes entre algumas danças sociais - como branles, pavanas e principalmente a courante - e formas cênicas de dança da época, principalmente as mascaradas (McGowan, 1978, p. 32).

O mestre de dança Cesare Negri publicou, em Milão, a segunda edição de seu tratado Le Gratie d'amore (1602), acrescida de novas composiçôes em dança, razáo pela qual a obra recebeu o título Nuove inventioni di balli $(1604)^{14}$. Na primeira parte do tratado, Negri traz uma exaustiva listagem de nomes de senhores e cavalheiros excelentes bailarinos na Itália dos seiscentos, indicando as cortes em que eles teriam dançado. $\mathrm{Na}$ segunda parte, instrui sobre regras de postura e gestual cortês como, por exemplo, a correta maneira de se fazer uma reverência, de se lidar com a capa e a espada, ou de como um cavalheiro deveria tomar a mão de uma dama ${ }^{15}$. Em seguida, descreve as regras de execuçáa de diversos tipos de passos e saltos, com especial dedicaçáo aos passos da galharda. A terceira parte apresenta composiçôes de dança e o nome das damas às quais são dedicadas. Enfim, uma estrutura muito semelhante aos tratados de Caroso.

A listagem de ilustres cortesãos bailarinos que inicia o tratado de Negri parece ter sido emulada pelo espanhol Juan de Esquivel Navarro no primeiro manual de dança impresso na Espanha: o Discursos sobre el arte del dançado $^{16}$ (1642). O tratadista ibérico também enumera nomes de cortesãos habilidosos na dança e de mestres afamados no reino. Mas o foco de Navarro reside no direcionamento da obra à figura do mestre de dança e a descrição das escolas e métodos didáticos, aspecto que não fora abordado pela tratadística do gênero até então. Tanto na obra de Negri quanto na de Navarro, a novidade dos nomes listados nos permite construir teias de relaçóes pessoais cortesás a partir da dança e do baile compreendidos como ambiente privilegiado de sociabilidade.

Retornando à França, o tratado Apologie de la danse $e^{17}$ (1623), de François de Lauze, alia o discurso erudito e a narrativa histórica e apologética às instruçóes práticas para o aprendizado da dança, distintamente apresentado para cavalheiros e damas. De Lauze confere grande destaque à noção de decoro social na dança: enfatiza a diferença entre as habilidades em dança de um cortesão e de um bailarino de ofício, desaconselhando o primeiro a aplicar-se na realização de passos demasiadamente difíceis, artificiosos e salta- 
dos, próprios da danse par haut (dança saltada) e náo condizentes com a condição do nobre.

Tais tratados conheceram ampla circulação em cortes de diversas regióes da Europa, tendo sido reimpressos, reeditados e traduzidos em outros idiomas ao longo dos seiscentos, e constituindo acervos de bibliotecas senhoriais e reais. Em levantamento recente, Nathalie Lecomte (2014, p. 92 e 224) lista 23 tratados e coletâneas de danças escritos entre 1515 e 1623, nas principais cortes italianas, França, Espanha e Inglaterra, o que evidencia o processo de consolidação da dança como arte e, também, a sua importância social.

A concepção de dança como arte na Europa Moderna teve implicaçôes definitivas. Uma vez regulamentada, formalizada e sistematizada em códigos (corporais e gráficos) cada vez mais específicos, o domínio dessa arte tornava-se restrito a um grupo de iniciados que conheciam e praticavam suas regras, códigos e formas. Uma vez que essa sistematizaçáo se constituiu tal como registro escrito e impresso, a dança passava ao domínio da erudição e do letramento, tornando-se, portanto, reservada a uma camada social privilegiada. Dessa maneira, a arte da dança permitia demarcar a distinção social de um grupo particular de indivíduos, uma vez que o acesso ao conteúdo letrado e ao aprendizado e refinamento de gestos não se estendia à população como um todo.

Assim, a partir do século XV, com o processo de formação de sociedades e de etiquetas cortesâs, sobretudo nas cortes italianas, francesa e borguinhã, a dança metrificada pouco a pouco se consolida como uma dança erudita. Essa se torna propriedade e símbolo de uma camada social que busca definir sua superioridade hierárquica tanto pelo refinamento intelectual e estético-artístico (baseado nos cânones da cultura antiga clássica) quanto pela elegância e distinçáo do corpo, do comportamento e do gestual. A multiplicação de manuais de dança em paralelo a uma série de tratados de civilidade (Elias, 2011) a partir do século XVI, contribuiu para "[...] a construção da figura do cortesão-bailarino como ideal corporal, moral e político e testemunha do fato que a dança participa no processo de 'civilizaçấo' da nobreza" (Lecomte, 2014, p. 24).

A dança tornada arte, nos termos e no contexto do século XVI, passa a ser um dos pilares de sustentaçáo da nobreza cortesá, que a reivindica e 
pratica como demarcador de sua hierarquia social. Da mesma forma, os divertimentos e espetáculos dançados, e aqui nos referimos especialmente aos balés de corte, tornam-se muito apreciados e cada vez mais recorrentes na corte francesa a partir de fins do século XVI. Assim, também os balés passam a ser concebidos e preceituados como arte, o que redundou em uma ampla produção escrita (tratados, libretos, discursos) que visava estabelecer regras específicas de composição, bem como sua vinculação a preceitos eruditos e ao decoro, característicos do ambiente cortesão.

Nesse contexto, dança e balé foram teorizados como artes poéticas, segundo a tradição aristotélica, como mímesis por seu caráter imitativo da natureza e das paixóes da alma (Aristóteles, 2008). Dessa maneira, seus princípios e regras passam a ser considerados análogos, comparáveis e influenciáveis pelos das demais artes poéticas - como a pintura, a música, o teatro e a poesia.

Faz-se necessário, portanto, debruçar-nos sobre o conjunto de regras e preceitos de composição dos balés que permitem compreendê-lo como uma arte, na acepção da época, e que nos possibilitam maior profundidade e propriedade em sua análise e interpretação. $\mathrm{O}$ caráter relativamente tardio da escrita de tratados e discursos voltados ao estabelecimento das normas do gênero ballet de cour, em relaçáo ao uso e recorrência desse espetáculo desde fins do século XVI, não implica na ausência de regras de composição e em um suposto espontaneísmo. Ao contrário, parece-nos que tais obras escritas vieram sistematizar saberes empíricos que, por muito tempo, foram difundidos e transmitidos oralmente - e não será demais sublinhar que a tradição oral permaneceria muito importante na composiçáo coreográfica mesmo após a instituição de tratados escritos.

\section{A arte de compor balés: tratados e discursos}

O termo ballet, derivado do italiano balleto $^{18}$, é utilizado nos manuais do século XV e XVI para designar um pequeno baile, mas também poderia designar uma composição de danças com alguma intençáo cênica relacionada a uma trama dramática frágil ou pantomima - podendo ser executada tanto num baile quanto em um espetáculo (Lecomte, 2014, p. 25). Segundo Lincoln Kirstein, somente sob influência do humanismo francês, a partir da segunda metade do século XVI, o termo ballet passaria a fazer referência 
a divertimentos com maior unidade dramática, maior coerência e um enredo elaborado em torno de determinada ação, caso do ballet de cour francês e do gênero inglês masque (Kirstein, 1977, p. 816).

Com efeito, é a partir do libreto do Ballet Comique de la Reine (1581), de Balthasar de Beaujoyeulx (1535-1587), que balé começa a ser compreendido como um gênero específico de espetáculo coreográfico, cuja composição deveria obedecer a certas regras e padróes que lhe confeririam beleza, coesáo e coerência. Ainda persistiria o uso do termo balé no sentido de baile ou pequena coreografia cênica, passando a fazer referência, ao mesmo tempo, ao espetáculo total e às suas partes (entradas) dançadas. Contudo, interessa-nos, aqui, sua designação como gênero de espetáculo e, pelo esforço de definiçấo das regras de composição, como arte.

Enquanto tratados e manuais de dança já vinham sendo publicados desde o século XV, circulando com grande popularidade ao final do XVI, destaca-se que, somente em 1641, foi publicado o primeiro tratado sobre os balés de corte La manière de composer et faire réussir les ballets ${ }^{19}$, escrito por Nicolas de Saint-Hubert. Apenas em 1682 seria publicado outro tratado específico sobre o gênero, o Des ballets anciens et modernes selon les règles $d u$ théâtre ${ }^{20}$, do jesuíta Claude-François Ménestrier (1631-1705) - esse de caráter mais estético e histórico, e que também propunha estabelecer regras e preceitos de composição. Entre os tratados de Saint-Hubert e Ménestrier há um longo intervalo de 41 anos, período de intensa produção de balés na corte francesa.

Todavia, esse intervalo de tempo não pode ser tomado como um absoluto silêncio a respeito das regras, preceitos e reflexôes sobre a composição de balés. Algumas obras contribuíram com apreciaçóes sobre o gênero, mesmo que esse não fosse o foco de seus objetivos. Em suas Memórias (1657), o abade Michel de Marolles (1600-1681) ${ }^{21}$ dedica o Nono Discurso aos balés: o autor apresenta sua apreciação geral sobre esse divertimento em um esforço de caracterizaçáo do gênero, descrevendo e comentando alguns balés específicos $^{22}$ (Marolles, 1755). O abade Michel de Pure (1620-1680), em sua obra Idée des spectacles anciens et nouveaux $x^{23}$ (1668), também dedica ao balé uma parte de suas reflexóes sobre os espetáculos antigos e novos (De Pure, 1972). Já Ménestrier, em obras anteriores a seu icônico tratado, faz pertinentes consideraçóes sobre os balés em Remarques sur la conduite des 
ballets $^{24}$ (1658) - um prefácio ao relato do espetáculo L'Autel de Lyon -, e também em Des representations en musique anciennes et modernes $(1681)^{25}$ (Ménestrier, 1972).

É curioso que todas essas obras teóricas sobre o balé tenham sido escritas tardiamente, isto se considerarmos a enorme quantidade e variedade de balés de corte que já vinham sendo representados desde fins do século $\mathrm{XVI}^{26}$. O próprio Ménestrier declara ser "[...] espantoso que desde tantos séculos, em que táo utilmente trabalhou-se para refinar e aperfeiçoar as artes, tenhamos ficado até aqui sem regras e sem preceitos para a composição dos balés" (Ménestrier, 1972, p. 1) - o que, aliás, demonstra o desconhecimento ou a desconsideração dos escritos de Saint-Hubert e Marolles. A ausência de tratados específicos até a publicação da obra de Saint-Hubert, e depois entre 1641 e 1682, pode gerar a impressão equivocada de ausência de preceitos e regras de composiçáo, isto é, de um gênero arbitrário, livre e experimental, “[...] sem regra, sem teoria, sem outro juiz que o prazer, sem outro objetivo além da satisfação coletiva" (Durosoir, 2004, p. 11), o que muitas vezes fundamenta um juízo depreciativo que se faz atualmente do balé de corte como espetáculo menor ou fútil.

É fato que os usos e a experiência prática também assumem importante função normatizadora, na medida em que oferecem modelos de composição, temas, formas e recursos técnicos a serem reproduzidos a partir das experiências prévias (Durosoir, 2004, p. 24) - o que se verifica na tradição das artes performáticas em geral. Assim como a noção aristotélica de teoria náo se opóe à prática, por ser entendida como contemplação ativa, consideramos pertinente pensar que saberes da dança se instituem e se sistematizam também no corpo e na coreografia. A esse respeito, Mark Franko muito bem sintetiza:

O desenvolvimento tardio de uma teoria da dança vem, ao menos em parte, de nossa capacidade de admitir que a teoria é inerente ao ato em si de dançar. Não somente a teoria é um meio de organizar as ideias sobre a dança, mas o simples fato de dançar é em si um ato teórico. A teoria da dança não vem 'depois' da coreografia; ela é constitutiva da coreografia (Franko, 2005, p. 49).

Embora concordemos que, até meados do XVII, os preceitos de composição de balés se mostrem menos rígidos e suas formas pareçam mais vari- 
adas que em outros gêneros de espetáculo da época (tragédia e comédia, por exemplo), o estudo das fontes aqui apresentadas não permite supor, contudo, que o balé seja desprovido de regras, de sistematizaçáo ou de teoria. Acreditamos, porém, que o estabelecimento de princípios e regras para o balé de corte não se restringe à tradição oral e empírica - dimensão dificilmente acessível à pesquisa histórica -, podendo também ser localizado, no âmbito da cultura letrada, em outros gêneros que não os poucos tratados: destacamos as obras anteriormente citadas (Marolles, 1755; Ménestrier, 1658 e 1972; De Pure, 1972) e os próprios libretos de balés.

\section{O libreto como modelo de composiçáo de balés}

Marcel Paquot, em seu artigo sobre as preceptivas teóricas do ballet de cour, já propunha compreender a natureza e as regras do balé antes pelos libretistas (especialmente Beaujoyeulx) que pelos chamados teóricos do balé, nomeadamente Marolles (1657), De Pure (1668) e Ménestrier (1682) (Paquot, 1957). Segundo o autor, tais obras teóricas apresentam certos limites para a compreensão dos balés de fins do século XVI e da primeira metade dos seiscentos. Esses tratados e discursos se inseririam em um contexto de transformaçáo das próprias concepçôes do gênero, em um processo de enquadramento das formas e usos dos balés às regras da comédia e da ópera.

A partir de meados dos seiscentos, o balé de corte teria sido reorientado para o gênero da comédie-ballet ${ }^{77}$ de Lully e Molière e de uma prática de composiçáo cada vez mais submetida ao controle das Academias ${ }^{28}$ (de música, de poesia, de dança) - instituiçóes sistematizadoras do saber e do fazer artístico que se constituíam de maneira mais sólida naquele momento. Assim, Paquot defende que esses escritos teóricos do gênero informam mais sobre a reorientação de concepçôes, de preceitos e de gosto, do que sobre o caráter dos balés em seus primeiros setenta anos - o que seria mais facilmente percebido nos próprios libretos das representaçóes (Paquot, 1957).

Os libretos tinham a finalidade de descrever o espetáculo, apresentando seu argumento, sua estrutura de entradas e personagens, os versos dos poemas cantados e, quando era o caso, os cortesãos e as damas que desempenhavam os papéis. Alguns deles mostram-se ainda mais completos, compondo-se de prefácios explicativos, discursos e consideraçóes. Isso pode ser verificado em alguns libretos de Guillaume Colletet $^{29}$ ou no início do li- 
breto do Ballet de la Prosperité des Armes de France (1641), por exemplo, que esboça uma sintética definição do gênero: "Os balés são comédias mudas e devem, portanto, se dividir em atos e cenas; os recitativos separam os atos e as entradas dos dançarinos são as cenas" (Lacroix, 1868-1870, p. 34). Além disso, libretos mais elaborados apresentam gravuras, partituras musicais, ou mesmo descriçóes de detalhes dos cenários, figurinos e/ou da própria representação - isso no caso dos libretos publicados após a realização do espetáculo, em forma de relato ou relação.

O libreto aparece, assim, como fonte privilegiada de informação sobre a estrutura, regras e formas de composição dos balés. Isso significa entendêlo, para além de sua função de registro de um evento passado, mas como uma forma possível de se estabelecer fundamentos teóricos e regras do gênero. É verdade que sua forma náo se enquadra no gênero retórico deliberativo, no qual se inscrevem os tratados e manuais da cultura escrita moderna. No entanto, os libretos se tornaram modelos de emulação e acabaram por exercer essa função prescritiva, mesmo que indireta e despretensiosamente.

$\mathrm{O}$ estudo dessas fontes permite-nos afirmar, portanto, que o conjunto de libretos compóe um corpo prescritivo do balé complementar aos tratados. Sobretudo, devido ao seu conteúdo sistemático e exemplar, o libreto mostra-se especialmente eficaz como modelo e diretriz de composiçáo, uma vez que se relaciona à dimensão mais prática e cotidiana, no contexto de invenção dos divertimentos de corte.

Conhecer os princípios teóricos, os preceitos e as regras, que orientam tanto a composição quanto a apreciação de um balé, mostra-se fundamental para compreendermos suas formas e sentidos - que náo se separam da dinâmica social e política francesa nos seiscentos. Para tanto, dispóe-se de um conjunto de fontes composto por tratados, discursos e libretos bastante detalhados ${ }^{30}$ que sistematizam os preceitos de invenção dos balés. Buscaremos, a partir desse ponto de nosso estudo, apresentar os princípios eruditos, os preceitos de composiçáo e os principais elementos que caracterizam o balé de corte, tomando por base tratados, discursos teóricos e libretos.

\section{Os princípios teóricos e eruditos que orientam a composiçáo do balé}

Claude-François Ménestrier inicia seu tratado afirmando que “[...] de todos os espetáculos e divertimentos que os gregos inventaram, ou aperfei- 
çoaram, nada há de mais universal que os balés" (Ménestrier, 1972). Ao atribuir a invenção do balé aos gregos antigos, o tratadista confere autoridade ao espetáculo moderno, traçando uma linha de continuidade que vincula o balé ao drama grego, tido como o grande modelo de espetáculo total.

De semelhante modo, tal referência aparece em versos do poeta Billard no libreto do Ballet Comique de la Reine: "Beaujoyeulx, o primeiro que das cinzas da Grécia / Fez renascer o propósito e a habilidade / Do balé compassado e mesurado" (Beaujoyeulx, 1582, n.p.). A invenção de Beaujoyeulx é elogiada como uma recuperação da tragédia grega clássica, perdida desde a antiguidade, que poderia ser revivida no balé, cujo desígnio, funçáo e forma (mesurada à antiga) seriam os mesmos de outrora.

Essa atribuiçáo da origem do balé aos antigos gregos, que não deve ser ingenuamente tomada como dado histórico objetivo, é uma tópica reiteradamente mobilizada em praticamente todos os discursos sobre o gênero. Isso evidencia as aspiraçôes humanistas que, desde início do século XVI, buscavam fazer reviver o drama grego antigo - ou, talvez, os desejos e suposiçôes próprios que os letrados modernos projetavam na Grécia antiga.

Especialmente os poetas e músicos da Academia de Música e de Poesia, coordenada por Baïf, empreendiam tentativas e experiências poéticas na direção de unir poesia e música, buscando adequar métrica e melodia a partir da inspiração na antiguidade grega. Com isso, tinha-se a intenção de amplificar os efeitos de ambas as artes, que se tornariam ainda mais poderosos se combinados. A aspiração ao princípio de uniáo das artes fica evidente no prefácio do libreto do Ballet Comique de la Reine: Beaujoyeulx propóe mesclar os gêneros do balé e da comédia, que dáo título ao espetáculo, assim como amalgamar música e poesia (Beaujoyeulx, 1582, prefácio).

A ideia do balé de corte como ressurgimento do drama grego antigo, em um "[...] baile compassado e mesurado" (Beaujoyeulx, 1582, n.p.), bem como a possibilidade de fazer reviver seus objetivos e efeitos, delineia as formas e os significados do gênero. O balé aparece, aos olhos de seus contemporâneos franceses, como gênero essencialmente compósito e especialmente eficaz em seus efeitos, por ser o único capaz de fundir poesia, música, dança e pintura. Assim estruturado, o balé produziria efeitos intensos a ponto de transbordar a própria cena, prolongando-se na vida social. 
No libreto do Ballet Comique, Beaujoyeulx manifesta suas intençóes de fundir todas as artes, de "[...] entrelaçar poesia e música", misturando-as à comédia, à decoração e à dança - à qual atribui "[...] primeiro título e honra":

Assim, animei e fiz falar o balé, e fiz cantar e ressoar a comédia: e acrescentando aí diversas representaçóes e ornamentos raros e ricos, satisfiz, num corpo bem proporcionado, os olhos, os ouvidos e o entendimento (Beaujoyeulx, 1582, n.p.).

Da mesma maneira como se acreditava terem sido as tragédias antigas, fica claro que esse princípio de fusão das artes num corpo bem proporcionado buscava estimular e agradar a todos os sentidos e ao intelecto. De fato, a teorização moderna das artes poéticas, fundamentada em Aristóteles (384 a.C.- 322 a.C.), Horácio (65 a.C.- 8 a.C.) e em pensadores modernos, postulava ser mais fácil tocar a razáo pelos sentidos, já que a mobilização das paixóes humanas deixaria a vontade mais dócil a absorver ideias e discursos. Seguindo a tópica docere-delectare, as representaçóes e divertimentos seiscentistas buscavam unir o sério e o agradável, verdade e fantasia, racional e sensorial. Seu intuito era o de ensinar agradando, ou agradar ensinando. Essa noçáo aparece claramente no prefácio do libreto do Ballet du Grand Demogorgon (1633):

E uma vez que a poesia, a música e a dança foram inventadas para tornar a verdade mais amiga dos sentidos, que devem levá-la ao espírito, elas são como pílulas douradas e tão bem escondem a verdade que, por ingênuas que possam ser, é preciso ajudar os espíritos a demonstrar seus mistérios (Grand Pré, 1633, n.p.).

As postulaçóes de Aristóteles, de Horácio e de Plutarco (46 d.C. - 120 d.C.) sobre a arte poética fundamentaram vários discursos, com destaque às analogias entre poesia e pintura, baseadas na tópica ut pictura poesis. Essa célebre premissa horaciana propóe aproximar as duas artes estabelecendo que a pintura é poesia muda, assim como a poesia é pintura falante. Enquanto formas imitativas, seus supostos e preceitos poderiam ser correspondentes e intercambiáveis.

A comparação entre essas duas artes irmãs, que dispunham de meios diferentes para o mesmo fim, serviu como tema para vários discursos, redundando na produçáo de um vasto repertório argumentativo. A possibili- 
dade de se estender a argumentação às demais artes, em processo de teorização entre os letrados seiscentistas, já havia sido sinalizada por Plutarco. Retomando o poeta grego Simônides (556 a.C. - 468 a.C.), Plutarco propóe a substituição, no dito horaciano, da pintura pela dança:

Assim, seria necessário transferir os dizeres de Simônides da pintura ao baile, uma vez que o baile é uma poesia muda e a poesia um baile falante (...). Entre o baile e a poesia todas as coisas são comuns, uma e outra em tudo participam, ambas representando uma mesma coisa, da mesma forma que as cançóes para dança (...), em que a representaçáo se faz de maneira mais eficaz, de uma parte pelos gestos e mímicas e, de outra, pelas palavras (Plutarco apud McGowan, 1978, p. 12).

Assim como a dança pôde ser entendida pelos antigos como poesia muda, capaz de falar por meio de gestos, pensadores modernos como Guillaume de Colletet (1598-1659) puderam considerá-la como imagem em movimento, ou ainda, como poesia animada. Comparada ora a uma tela, ora a um discurso, a dança teria a capacidade de dizer e mostrar as paixóes, açóes e pensamentos humanos:

Se os antigos chamaram à poesia pintura falante, e à pintura uma poesia muda, a seu exemplo podemos chamar a dança, e sobretudo aquela que se pratica em nossos balés, de uma pintura movente ou uma poesia animada. Pois como a poesia é uma verdadeira tela de nossas paixóes, e a pintura um discurso mudo de fato, mas, todavia, capaz de despertar tudo aquilo que cai em nossa imaginação: assim a dança é uma imagem viva de nossas açóes e uma expressão artificial de nossos pensamentos secretos (Colletet, 1632a, n.p.).

Em outro libreto de 1632, Colletet se vale claramente da fórmula horaciana de correspondência entre as artes para propor a aproximaçáo entre música e dança. $\mathrm{O}$ autor compreende as duas artes como vias diferentes de manifestação do princípio divino da harmonia. Dessa maneira, concebe a dança como "[...] música para os olhos" e afirma ser possível "[...] ouvir um movimento", especialmente no balé, quando música e dança se fundem:

Mas aqui a ouvireis e a vereis [a harmonia] ao mesmo tempo, pelo que podereis perceber que não é incompatível fazer ver uma música nem tampouco ouvir um movimento. Portanto, compreende-se que a dança não é outra coisa que uma música para os olhos, assim como as vozes harmônicas o são para os ouvidos, e, as duas juntas, uma harmonia para uma e para outra (Colletet, 1632b, p. 3-4). 
Também Ménestrier numerosas vezes recorre à analogia entre dança, pintura e poesia. O balé como "[...] espécie mais perfeita de dança" (Ménestrier, 1972, p. 18) é comparado a um poema dramático ${ }^{31}$, e suas regras deveriam ser estabelecidas de acordo com os preceitos da pintura. Para defender essa ideia, o jesuíta evoca, mais uma vez, a autoridade de Horácio:

O balé é uma pintura, por ser uma imitaçáo, e Horácio já dizia desde muito tempo que era sobre a pintura que a poesia deveria ser regrada, de maneira que a poesia é uma pintura falante e a pintura é uma poesia muda Ut picture poësis erit. As regras de um balé são, portanto, semelhantes às de um quadro (Ménestrier, 1972, p. 82).

Assim, é possível perceber, nas formulaçóes dos pensadores da dança no XVII, o desenvolvimento de uma ideia correspondente à tópica horaciana: uma ut pictura saltatio. A comparação entre balé e pintura iria além: por ser constituído do movimento dançado, o balé foi concebido como uma pintura viva ou, ainda, uma imagem de ação. Segundo Marie-Thérèse Mourey (2009), essa analogia sistemática poderia ser entendida como uma "[...] poética da imagem animada". Como em uma tela, os balés representariam imagens, desenhos, cores e símbolos por meio da decoraçáo, dos elementos cênicos e dos figurinos. Para além disto, o balé teria a capacidade de transformar imagens estáticas (de uma pintura) em imagens animadas, por meio dos movimentos, gestos e deslocamentos espaciais dos bailarinos - o que possibilitaria exprimir ainda melhor as açóes, paixóes e mesmo noçóes abstratas em seu movimento processual (Mourey, 2009, p.15). Como bem expressa o jesuíta:

Mas o balé tem vantagem sobre a pintura, pois a pintura tem apenas um momento, de maneira que todas as suas figuras permanecem sempre na mesma situaçáo (...), ao contrário do balé que é toda uma sequência de movimentos que se sucedem uns aos outros (Ménestrier, 1972, p. 157).

Baseado nisso, os teóricos e apologistas do balé construíram o argumento da superioridade do balé em relação à pintura e demais artes, já que a dança acrescentaria movimento às figuras e vida às representaçóes. A poética da imagem animada decorre da compreensão do balé como pintura viva: uma poética da imagem dinâmica, investida de sentido e vida através do movimento dançado, que teria potencialidades particulares e ainda mais 
persuasivas, sendo capaz de produzir um efeito impressionante antes mesmo de qualquer interpretação racional (Mourey, 2009).

A argumentaçáo dos teóricos sugere que a dança poderia ultrapassar as demais artes tanto em suas possibilidades imitativas quanto em intensidade. Essa peculiar eficácia poética da dança se sustentaria pelos gestos e movimentos do corpo, capazes de conferir “[...] vida” às imagens, exprimindo, assim, a natureza das coisas, as "[...] açôes, costumes e paixôes", as noçóes puramente intelectuais e os "[...] mistérios mais ocultos da natureza" (Ménestrier, 1972 p. 40-41). Para Ménestrier, somente o balé poderia exprimir, em um mesmo espetáculo, tanto as açóes inferiores (comédia) quanto as ações de grandes homens (tragédia), misturando, o histórico e o fabuloso, o sério e o ridículo, o heroico e o satírico, como nenhum outro gênero poderia fazê-lo (Ménestrier, 1972, p. 53-55, p. 124).

A ideia de que a dança poderia "[...] tudo exprimir" e o balé "[...] tudo representar" aparece disseminada no pensamento da época e fundamenta, por exemplo, a percepção de Michel de Pure sobre tal arte como uma espécie de pintura que reflete o mundo e a história, revelando os mistérios da natureza e da moral (De Pure, 1972, p. 211-212). Acreditava-se que a dança era capaz de abarcar uma vastidáo de assuntos e áreas (McGowan, 1978, p. 14). Marin Mersenne (1588-1648), teólogo e matemático francês, defendeu a grande utilidade da dança nos tratamentos de medicina, bem como meio muito eficaz no estudo dos movimentos celestes (através das figuras espaciais de dança) e de ciências aplicadas, como a mecânica e a perspectiva, chegando a defender a dança como uma linguagem universal (Mersenne, 1636, p. 159-160).

Como procuramos demonstrar, todos esses princípios eruditos - de restauração do drama grego antigo, de fusão das artes, de analogias entre poesia, pintura e demais artes poéticas, de uma poética da imagem em movimento e de uma arte eloquente - aparecem claramente nos tratados, libretos e discursos sobre os balés para definir o gênero e orientar sua composição, presidindo e circunscrevendo em seu bojo as regras eminentemente técnicas e práticas. Dessas últimas, trataremos a seguir.

\section{Preceitos e regras de composiçáo dos balés}


Nicolas de Saint-Hubert, mestre de dança, inicia seu pequeno tratado La manière de composer et faire réussir les ballets, legitimando a importância da dança como um dos três principais exercícios da nobreza, assim como montar a cavalo e manejar armas:

[...] a dança é um dos três exercícios principais da Nobreza (...) Todos sabem que para bem educar um jovem Cavalheiro é necessário que ele aprenda a montar a Cavalo, a Manejar armas e a Dançar. O primeiro aumenta a destreza, o segundo a coragem e o Último a graça e a disposição (...) (Saint-Hubert In: Couto, 2020, p. 476).

Com essa afirmação, o autor reitera a importância da dança na educação da nobreza e na sociabilidade cortesá, o que a insere em uma lógica de concepção e apreciaçáo regida por normas e princípios eruditos, discretos e letrados. Nesse primeiro tratado de ballets de cour, Saint-Hubert postula as principais regras e características do gênero, além de recomendações bastante práticas e questôes de ordem técnica importantes na elaboraçáo e realização de um balé (Roucher, 1999, p. 380-381). Os balés são classificados pelo número de entradas como pequenos, belos e grandes (balés Reais). Pela natureza do tema, são definidos como sérios ou grotescos.

O autor define seis aspectos principais e necessários à invenção de um balé: o tema, as músicas, a dança, a vestimenta, as máquinas e a ordem (Saint-Hubert In: Couto, 2020, p. 476). E sobre cada um deles desenvolve seus comentários, regras e considerações.

Ao postular esses seis elementos, o tratadista demonstra, antes de tudo, conceber o gênero conforme o princípio humanista, já aqui abordado, de uniáo das artes: a poesia (presente no tema, recitativos e árias cantadas), a música (tanto música vocal quanto música para dança), a pintura (na decoração, cenário e vestimentas), a engenharia das máquinas cênicas e a própria dança. Esses mesmos elementos permanecerão centrais nos discursos posteriormente publicados, o que demonstra a permanência da sistematizaçáo de Saint-Hubert.

Para Saint-Hubert, o principal para se fazer um belo balé seria encontrar um bom tema, dependendo dele e submetendo-se a ele todo o restante (Saint-Hubert In: Couto, 2020, p. 477). Também De Pure identifica no tema "[...] a alma do balé", entendendo-o como elemento definidor que daria "[...] alimento e movimento" ao espírito e às ideias do poeta (De Pure, 
1972, p. 214). Ménestrier concebe três sortes de temas (ou matérias): os históricos (que em geral remeteriam à história antiga, mas também poderiam aludir a episódios da história moderna), os fabulosos ou mitológicos e os poéticos ou alegóricos, temas poderiam e deveriam ser combinados (Ménestrier, 1972, p. 53).

Dessa maneira, um só gênero seria capaz de exprimir variadas espécies de coisas: coisas naturais, acontecimentos, poemas épicos, ensinamentos morais ou, ainda, puro capricho, como em alguns balés burlescos. Ainda assim, os temas poéticos, alegóricos e morais eram considerados os mais elevados. Independentemente da escolha do tema, o balé deveria causar a admiraçáo e o prazer, o que seria conquistado pela graça da novidade e pela exatidão da imitação (Ménestrier, 1972, p. 113). De fato, "[...] para ser belo, é preciso que ele [o tema] nunca tenha sido feito", que seja novo (SaintHubert In: Couto, 2020, p. 477).

Se os princípios da novidade e da diversidade deveriam orientar a invenção de qualquer espetáculo, eram considerados essenciais na composição dos balés de corte, pois entendia-se que eles deveriam sempre apresentar algo novo e diverso. Náo é fortuito, portanto, que todos os tratados e discursos sobre os balés deem relevo à descriçáo e/ou preceituação do aparato cênico, da decoração, da caracterização dos personagens (figurinos, acessórios e movimentos) e das máquinas. Para Saint-Hubert, as vestimentas e as máquinas aparecem como aspectos táo importantes quanto a dança e a música. De Pure discorre sobre o figurino, as máscaras e as máquinas em sessóes específicas de seu tratado (De Pure, 1972, p. 285-304) e Ménestrier considera essencial a atençáo ao aparato cênico, que inclui decoraçáo, vestimentas e máquinas (Ménestrier, 1972, p. 212-223 e p. 245-257). Já Michel de Marolles atenta para o quanto um descuido com a decoraçáo poderia pôr a perder toda uma representação (Marolles, 1755).

Essa insistente preocupação com o aparato cênico e com a caracterização dos personagens revela o gosto da época pelo ornamento, pelo artifício e pelo impacto espetacular. Mas para além do gosto, o aparato cênico mostrase essencial para a composição das alegorias como emblemas vivos, que têm papel central na representação, na medida em que evidencia os elementos icônicos (do personagem e do cenário) que investem a cena de significado. Nesse sentido, Saint-Hubert insiste em que trajes, decoraçôes e máquinas 
estejam sempre adequados e convenientes àquilo que representam: "[...] não necessariamente devem ser belíssimos, desde que sejam feitos de acordo com o tema" (Saint-Hubert In: Couto, 2020, p. 481), ao que oferece uma série de exemplos.

Segundo Ménestrier, os movimentos e os gestos também seriam meios essenciais de se caracterizar os personagens, sempre baseado num repertório alegórico e preceituado de se exprimir as coisas "de maneira muda" (Ménestrier, 1972, p. 153). A dança, os movimentos e os gestos são, portanto, entendidos como elementos importantes da construção poética e alegórica na representação da natureza ou das açóes, afetos e costumes dos homens:

É por meio dos movimentos que os balés imitam as coisas, imitando pelos movimentos as açóes dos homens, suas afeiçōes, seus costumes, assim como imitam os movimentos naturais dos animais e aqueles que recebem, natural ou violentamente, todos os demais corpos (Ménestrier, 1972, p. 153).

Isso já havia sido apontado por Saint-Hubert, que reforçava a importância, tanto da dança quanto dos trajes, na caracterização dos personagens: "[...] uma vez que o balé é uma comédia muda, é necessário que os trajes e as açóes permitam reconhecer aquilo que se representa" (Saint-Hubert In: Couto, 2020, p. 480). Parece-nos claro que o autor demonstra compreender que diferentes tipos humanos e sociais teriam, necessariamente, corpos e gestuais também distintos. Assim, tais características particulares deveriam ser convenientemente representadas na dança: "É necessário submeter a dança e os passos às músicas, às entradas, e não colocar um produtor de vinho ou um carregador de água para dançar como um cavaleiro ou um mago" (Saint-Hubert In: Couto, 2020, p. 479). Daí, a necessidade de se "[...] reservar um tempo para estudar os passos e as entradas", e náo os deixar ao improviso (Saint-Hubert In: Couto, 2020, p. 480).

Segundo Ménestrier, o balé não necessitaria obedecer a uma unidade de ação ou uma trama coerente, como a tragédia e a epopeia, mas somente uma unidade de tema, de desígnio. A coerência e a unidade do balé consistiriam, assim, em que todas as partes mantivessem uma relação com o todo: não por representarem uma única açáo, mas por se referirem todas elas ao mesmo tema (Ménestrier, 1972, p. 114). Esse aspecto nos conduz a outro elemento importante, que Saint-Hubert chamou de ordem e Ménestrier nomeou condução ou economia dos balés: 
A economia dos balés é a justa distribuição de um todo em suas partes essenciais e decorosas, o justo arranjo de causas, efeitos, propriedades, circunstâncias, eventos, sequência de fábulas e exemplos e imaginaçôes de um mesmo tema. (Ménestrier, 1972, p. 135)

Essa concepção de partes específicas que se referem a um todo é o que orienta a estrutura do balé em entradas (entrées) ${ }^{32}$. Por meio das entradas organiza-se a disposição dos subtemas, dos personagens e dos elementos de um balé, visando assegurar a novidade e beleza pela diversidade de entradas, "[...] na variedade de figuras e uniformidade de passos" (De Pure, 1972 p. 237). Para orientar a disposição harmoniosa de todas as partes e garantir o equilíbrio entre elas conforme o tema, Saint-Hubert insiste na importância do ofício do mestre de ordem, responsável pela concepção e coordenação do balé em sua totalidade: "[...] pois da sua boa condução depende inteiramente o sucesso ou o insucesso" do espetáculo (Saint-Hubert In: Couto, 2020, p. 4784). Assim como um orador organiza suas tópicas na construção de um discurso (dispositivo), essa ordem, ou economia, proporcionaria, ao inventor de balés, a melhor maneira de encadear os temas, imagens, recursos cênicos e alegorias, para melhor evidenciar o seu intento.

Entre todos esses preceitos, um aspecto ganha destaque por presidir a todos os elementos da composiçáo e é assim sintetizado por De Pure: "[...] a primeira e mais essencial beleza de uma ária de balé é a conveniência, isto é, a justa relação que a ária deve ter com a coisa representada” (De Pure, 1972 p. 260). A ideia de conveniência serviria para adequar e ajustar todos os elementos do balé, submetendo-os, cada um, a todos os demais. Isso visava garantir a verossimilhança da representação e o decoro exigidos, ajustando a representação ao ambiente e à circunstância em que se insere, bem como aos sujeitos que dela participam.

É importante destacar que os tratados e discursos, aqui abordados, apresentam tais preceitos e regras a partir de inúmeros e frequentes exemplos: tanto são citados balés considerados excelentes quanto experiências malsucedidas, trechos e aspectos que ora ilustram o êxito, ora sáo dignos de reprovação. Se esses exemplos nos revelam hoje interessantes detalhes - como uma bela ou má execução de dança, os materiais de confecção de trajes ou ainda os temas e o desenvolvimento de determinadas entradas -, parece- 
nos que também aos mestres e bailarinos daquela época deveriam elucidar aspectos bastante práticos da composição de balés.

Assim, reiteramos que o esforço de elaboraçáo escrita das preceptivas do balé em tratados e libretos não se opóe às práticas de composição, ao contrário, esses textos têm caráter prático e orientam diretamente o fazer artístico da dança cênica.

\section{Consideraçóes finais}

O esforço teórico empreendido por Saint-Hubert, Ménestrier, De Pure e Marolles - e de libretistas como Beaujoyeulx, Grand Pré e Colletet para definir, classificar e preceituar o balé, demonstra não apenas um crescente interesse pelo espetáculo coreográfico na França seiscentista, como também uma busca por rigor e legitimação do balé como arte (poética), segundo a concepçáo vigente naquela época. Assim, segundo Christout, "[...] percebe-se uma preocupaçáo nova de ordem e método. Respeitando a liberdade inerente ao gênero, busca-se precisar as leis que lhe são próprias e, também, os limites de seu domínio" (Christout, 2005, p. 150).

Em suma, no decorrer do presente trabalho, buscamos evidenciar o processo pelo qual a dança e especialmente o balé de corte foram sistematizados como arte, sendo central nessa dinâmica a produçáo de documentos escritos (e impressos) na forma de manuais, tratados, libretos e discursos. Essa tradução para o campo da escrita tem implicaçôes muito relevantes na teorização da dança e do balé, o que as insere em um contexto maior de sistematizaçáo do conhecimento na Europa moderna. Esses preceitos e regras escritas a que chamamos de corpus teórico do balé tinham caráter evidentemente prático, uma vez que orientavam os mestres de balé na invençáo, composição e condução, bem como na apreciação deste espetáculo tão presente no cotidiano da corte francesa no século XVII.

O entendimento dos preceitos norteadores da composição dos balés de corte nos permite uma melhor compreensão e aprofundamento de análise dos espetáculos coreográficos e formas cênicas da dança daquela época. Uma vez compreendidasas regras e as partes constitutivas desse gênero, bem como aquilo que seus contemporâneos consideravam bom e conveniente (ou aquilo que era reprovado e desaconselhado), abre-se espaço para consi- 
deraçôes historicamente contextualizadas e evitam-se conclusôes superficiais e anacrônicas.

Nesse contexto, em que a dança e o balé se inserem na sociedade de corte, caracterizada pela codificaçáo do comportamento também expressa no domínio da cultura letrada, a nobreza francesa se apropriou dessas artes como artifícios simbólicos potentes por meio dos quais buscou constantemente reafirmar sua distinção social e sua hegemonia política na França do Antigo Regime. Não se pode perder de vista que o esforço de elaboração e sistematizaçáo minuciosa de regras e preceitos artísticos esteve intimamente relacionado ao poder monárquico, na medida em que os espetáculos de corte se colocavam a serviço do rei e de mensagens políticas muito claras, bem como das estratégias de reafirmação dos pactos sociais e políticos que visavam manter a corte francesa em harmonia (Couto, 2015).

É certo que os princípios eruditos, preceitos e regras de composição dos balés foram elaborados na intençáo de melhor realizar seus objetivos retórico-poéticos de mover afetos e persuadir a corte envolvida nesse cerimonial coreográfico que era o balé. Fica claro, portanto, que o estudo sobre a dança e o balé de corte na época Moderna se insere no âmbito maior do estudo das práticas e representaçóes do poder monárquico e da sociedade que o legitima.

\section{Notas}

1 A pesquisa de mestrado contou com o financiamento da FAPESP, instituição que também possibilitou grande parte da pesquisa documental realizada em arquivos históricos franceses por meio do programa de Bolsa de Estágio de Pesquisa no Exterior-BEPE (2014).

2 As traduçóes do francês para o português ao longo do presente texto são de responsabilidade da autora.

3 Sobre os vários tipos danças no início da época Moderna, suas características estéticas, sociais, musicais e coreográficas, ver Bourcier, 2001 e Nevile, 2004.

4 Livro de 'baixas danças' da Biblioteca da Borgonha. Esse manuscrito de c. 1500 está conservado na Biblioteca Real da Bélgica. Refere-se às chamadas basses danses danças nobiliárquicas em andamento lento e executadas com passos deslizados no chão, sem elevação do corpo em saltos, o que era considerado mais 
solene e adequado à dignidade aristocrática. Nessa obra, as regras de dança aparecem associadas a exemplos musicais.

5 A arte de bailar e dançar. Domenico da Piacenza, De arte saltandi \& choreas ducendi, c. 1425. Paris, Biblioteca Nacional da França, Ms. fundo italiano 972. Uma versão digitalizada desse manuscrito, assim como da maior parte dos tratados aqui citados, pode ser acessada pelo portal digital Gallica da BNF.

6 Sobre a pratica ou arte da dança. Guglielmo Ebreo da Pesaro, De pratica seu arte tripudii vulgare opusculum.,1463. Paris, Biblioteca Nacional da França, Ms. fundo italiano 973.

7 Livro da arte de dançar. Antonio Cornazzano, Libro dell'arte del danzare, c. 1465. Roma, Biblioteca Apostólica Vaticana, Codice Capponiano 203.

8 O manuscrito está conservado no arquivo municipal da referida cidade (ECam, Fons notarial 3, 3). Cf.: NOCILLI, C. El manuscrito de Cervera: musica y danza palaciega catalana del siglo XV. Barcelona: Amalgama Edicions, 2013.

9 Arte e instrução para dançar bem.

10 Uma cópia digitalizada da obra de Antoine Arena Ad suos compagnes qui sunt de persona frantes, bassas danses et branles praticantes, datada de 1538, pode ser consultada no portal Gallica da BNF.

11 O bailarino.

12 Nobreza das damas.

13 Orquesografia. Para uma edição da obra traduzida para o inglês com introdução de Julia Sutton, ver ARBEAU, Thoinot. Orchesography. Translated by Mary Stewart Evans. With a New Introd. and Notes by Julia Sutton and a New Labanotation Section by Mireille Backer and Julia Sutton. New York: Dover, 1967. Para uma versão traduzida para o espanhol, ver ARBEAU, Thoinot. Orquesografía: tratado en forma de diálogo. Versión castellana del texto inglés traducido por Cyril W. Beaumont de la edición original publicada en Langres, en 1588. Buenos Aires: Centurion, 1946.

14 Graça de amor (1602) e Novas invençóes de danças (1604).

15 Sobre a relação do aprendizado da dança com a etiqueta e a importância da eloquência corporal no gestual cortesão, ver Burke, 2000, p. 91-112.

16 Discursos sobre a arte da dança.

17 Apologia da dança. 
18 Segundo as formulaçóes de Ménestrier, o nome ballet teria origem num termo grego cujo significado seria lançar, de onde viria o termo francês balle que faz referência a bola, objeto que afirma ter sido usado nas danças antigas (Ménestrier, 1972, p. 39). Também Michel de Marolles definiu o termo balé segundo o francês antigo: "Não tenho dúvidas de que Bal e Ballet tenham uma mesma origem e que ambos derivem de Baller, que significa dançar e saltar no francês antigo, segundo apontamentos de um erudito em sua obra Origens da língua francesa" (Marolles, 1657, p. 110 e 111).

19 A maneira de compor e fazer balés bem-sucedidos. Conservam-se atualmente apenas dois exemplares do pequeno tratado de Saint-Hubert: um na Biblioteca Mazarina (68146 Rés.), em Paris, e outro na Biblioteca do Conservatório Real de Liège (L071/3F04), na Bélgica. Uma edição fac-símile (atualmente esgotada) comentada por Marie-Françoise Christout foi publicada em 1993 (SaintHubert, 1993). Recentemente, publicamos uma traduçáo comentada do tratado de Saint-Hubert, de onde retiramos os trechos citados no presente artigo (Couto, 2020).

Balés antigos e modernos segundo as regras do teatro.

21 O clérigo francês Michel de Marolles (1600-1681), abade de Villeloin entre 1626-1674, deixou uma vasta obra escrita que compreende desde traduçóes (da Bíblia, de Ovídio, Virgílio e Sêneca, entre vários outros), história, memórias e genealogias, até catálogos de gravuras. Em suas Memórias, organizadas em três volumes e publicadas em 1657, fica clara sua inserção na vida de corte e dos salóes. Notadamente, tendo frequentado o círculo erudito de Mlle. de Scudéry, o autor descreve cerimônias, espetáculos e o cotidiano de corte, além de falar sobre sua relação com notáveis senhores e letrados. Nessa obra, Marolles dedica seu Nono Discurso aos balés, apresentando sua opinião geral sobre tal divertimento num esforço de caracterização do gênero, descrevendo e comentando algumas representações específicas de balés. Ao final, ainda apresenta quatro concepçóes de balés de sua autoria em forma de libretos, os quais, no entanto, não se pode ter certeza se chegaram a ser representados.

22 Ao final do discurso, Marolles ainda apresenta quatro concepçóes de balés de sua autoria em forma de libretos. Sobre esses, no entanto, não se pode ter certeza se chegaram a ser representados.

23 Ideia sobre os espetáculos antigos e novos.

24 Consideraçóes sobre a condução dos balés. 
25 Sobre as representaçóes musicais antigas e modernas. Há ainda o tratado La pratique du théâtre (A prática do teatro), publicado em 1657 pelo abade d'Aubignac (D’Aubignac, 1972), que tangencia o tema do balé reservando, a ele, apenas rápidas menções.

26 Segundo as listagens feitas por McGowan (1978, p. 251-309) e Durosoir (2004, p. 146-151), é possível indicar cerca de 500 balés realizados somente entre 1581 e 1643, fim do reinado de Luís XIII.

27 A comédie-ballet, gênero muito apreciado na corte de Luís XIV, apresenta uma tentativa de associar a música e a dança a uma ação teatral autônoma, de maneira que a função dramática prepondera sobre as demais artes, consideradas acessórias (Durosoir, 2004, p.111). Essa nova orientação resulta, segundo Paquot, em perda de autonomia do gênero ballet de cour, uma vez que, inserido nos quadros da comédia e da ópera, o balé perderia suas formas específicas, bem como dinâmicas e características definidoras - como a participação da nobreza na representação, por exemplo (Paquot, 1957, p. 197).

28 Sobre a constituição das Academias na França no século XVI, os principais temas de debate acadêmico e a rede de letrados e artistas aí envolvidos, ver Yates, 1947.

29 Ballet de l'Harmonie (1632), Ballet des Effects de la Nature (1632) e Ballet des Cinq sens de la Nature (1633). Grande parte dos libretos de balés de corte encontram-se atualmente digitalizados e disponíveis para consulta pública no portal digital Gallica da BNF.

30 Além do Ballet Comique de la Reine (1581), de Beaujoyeulx, existem outros libretos bastante detalhados, contando com prefácios, discursos e/ou comentários. É o caso dos libretos do Ballet de Monseigneur le duc de Vendôme (1610), o Ballet Le Triomphe de Minerve (1615), o Ballet de la Délivrance de Renaud (1617), o Ballet des Effets de la Nature (1632), o Ballet du Grand Démogorgon (1633), entre outros.

31 Comparações do balé ao teatro na mesma estrutura analógica do dito de Horácio são recorrentes nos escritos seiscentistas. Tanto Saint-Hubert (1993, p. 16) quanto o abade de Marolles (1755, p. 113) caracterizam o balé como "[...] comédia muda", e também De Pure o define como "[...] representação muda, em que os gestos e movimentos significam aquilo que se poderia exprimir pelas palavras" (De Pure, 1972, p. 210). 
32 A unidade essencial que compóe a estrutura dos balés é a entrée, ou entrada. A quantidade de entradas pode variar bastante, de modo que um balé grandioso e engenhoso deveria ter maior número e variedade de entradas. Em alguns balés as entradas são divididas em partes, embora isso não seja uma regra. A partir de meados do XVII, os libretos começam a distribuir as entradas em atos. Essa prática coincide com o momento de reorientação do gênero em direção à $c o$ médie-ballet de Lully, Benserade e Molière, quando o balé começa a ser preceituado sob as regras e formas da comédia.

\section{Referências}

ARBEAU, Thoinot. Orchésographie. Langres: Iehan des preyz, 1589. Disponível em: https://gallica.bnf.fr/ark:/12148/btv1b8610761x/f1.planchecontact. Acesso em: 10/09/2021.

ARISTÓTELES. Poética. Tradução, prefácio, introdução, comentário e apêndices de Eudoro de Sousa ( $8^{a}$ edição). Lisboa: Imprensa Nacional-Casa da Moeda, 2008.

BEAUJOYEULX, Balthasar. Balet comique de la Royne, faict aux nopces de monsieur le duc de Joyeuse \& madamoyselle de Vaudemont sa soeur. Paris: Adrian Le Roy, Robert Ballard \& Mamert Patisson, 1582. Disponível em: https://gallica.bnf.fr/ark:/12148/bpt6k1110737?rk=21459;2. Acesso em: 10/09/2021.

BOURCIER, Paul. História da dança no ocidente (2a ed.). São Paulo: Martins Fontes, 2001.

BURKE, Peter. A linguagem do gesto no início da Itália moderna. In: Variedades de história cultural. Rio de Janeiro: Civilizaçáo Brasileira, 2000. p. 91-112.

BURKE, Peter. O que é História Cultural? 2a ed. Rio de Janeiro: Jorge Zahar Ed., 2008.

CAROSO, Fabrizio. 11 ballarino. Veneza: Francesco Ziletti, 1581. Disponível em: https:/gallica.bnf.fr/ark:/12148/bpt6k1167910q?rk=21459;2. Acesso em: $10 / 09 / 2021$.

CAROSO, Fabrizio. Nobilità di Dame. Veneza: Il Muschio, 1600. Disponível em: https:/gallica.bnf.fr/ark:/12148/bpt6k58170c?rk=85837;2. Acesso em: 10/09/2021.

CHRISTOUT, Marie-Françoise. Le ballet de cour de Louis XIV, 1643-1672 - Mises en scène. Paris: Picard, 2005. 
COLleTET, Guillaume. Le Grand Ballet des Effects de la Nature. 1632a. Disponível

em:

https://gallica.bnf.fr/ark:/12148/bpt6k1512919g.r=Colletet\%2C\%20Guillaume \%20ballet?rk=42918;4. Acesso em: 10/09/2021.

COLLETET, Guillaume. Ballet de l'harmonie. 1632b.

COUTO, Clara Rodrigues. Baile celeste e harmonia terrestre: o balé de corte como imagem prescritiva da harmonia cósmica e política na França (1610-1661). São Paulo: Programa de Pós-Graduação em História Social/FFLCH-USP, 2015. Dissertação (Mestrado em História Social).

COUTO, Clara Rodrigues. A maneira de compor e fazer balés bemsucedidos: o primeiro tratado sobre balés de corte (Nicolas de Saint-Hubert, 1641). Revista de fontes, Guarulhos, UNIFESP, v. 07, n. 12, p. 470-485, julho de 2020.

CHARTIER, Roger. A história cultural: entre práticas e representaçóes. Rio de Janeiro: Bertrand Brasil, 1990.

D’AUBIGNAC. La Practique du théâtre (1657). Genebra: Éditions Minkoff, 1972.

DE LAUZE, François. Apologie de la danse et parfaite methode de l'enseigner tant aux Cavaliers que qu'aux dames. S.l., 1623. Disponível em: https:/gallica.bnf.fr/ark:/12148/bpt6k1040284n.r=De\%20Lauze\%2C\%20Fran \%C3\%A7ois?rk=21459;2. Acesso em: 10/09/2021.

DE PURE, Michel. Idée des spectacles anciens et nouveaux (1668). Genebra: Éditions Minkoff, 1972.

DUROSOIR, Georgie. Les ballets de la cour de France au XVIIe siècle ou le fantaisies et les splendeurs du Baroque. Genebra: Éditions Papillon, 2004.

ELIAS, Norbert. A sociedade de corte: investigação sobre a sociologia da realeza e da aristocracia de corte. Rio de Janeiro: Jorge Zahar Ed., 2001.

ELIAS, Norbert. O processo civilizador, volume 1: uma história dos costumes. 2a ed. Rio de Janeiro: Jorge Zahar Ed., 2011.

ESQUIVEL NAVARRO, Juan de. Discursos sobre el arte del dançado. Sevilla: Iuan Gomez de Blas, 1642.

FRANKO, Mark. La danse comme texte: idéologies du corps baroque. Paris: Kargo/l'Éclat, 2005. 
FURETIÈRE, Antoine. Dictionnaire universel, contenant généralement tous les mots françois tant vieux que modernes, et les termes de toutes les sciences et des arts. La Haye, A. et R. Leers, 1690, [n.p.].

GRAND PRÉ, César de. Ballet du Grand Demogorgon. Paris, 1633. Disponível em: https://gallica.bnf.fr/ark:/12148/bpt6k5789793r?rk=21459;2. Acesso em: 10/09/2021.

KIRSTEIN, Lincoln. Dance: A Short History of Classical Theatrical Dancing. Nova York: Dance Horizons Republication, 1977.

LACROIX, Paul. Ballets et mascarades de cour sous Henri IV et Luis XIII: 1581-1652 / recueillis et publiés d'après les éditions originales la plupart introuvables aujourd'hui. Genebra: J. Gay et fils, 1868-1870, 6 vol.

LECOMTE, Nathalie. Entre cours et jardins d'illusion : le ballet en Europe (1515-1715). Pantin: Centre National de la danse, 2014.

MAROLLES, Michel de. Mémoires de Michel de Marolles, abbé de Villeloin (1657). 3 vol. Amsterdam, 1755.

MCGOWAN, Margaret. Dance in the Renaissance: European Fashion, French Obsession. New Haven and London: Yale University Press, 2008.

MCGOWAN, Margaret. L'art du Ballet de Cour en France: 1581-1643. Paris: CNRS Éditions, 1978.

MÉNESTRIER, Claude-François. Remarques sur la conduite des ballets. L'Autel de Lyon, consacré à Louis Auguste et placé dans le Temple de la Gloire. Lyon: Jean Moulin, $1658 . \quad$ Disponível em: https://gallica.bnf.fr/ark:/12148/bpt6k315285g.r=M\%C3\%A9nestrier\%20repres entations\%20en\%20musique?rk=21459;2 . Acesso em: 10/09/2021.

MÉNESTRIER, Claude-François. Des ballets anciens et modernes selon les règles du théâtre (1682). Genebra: Éditions Minkoff, 1972.

MERSENNE, M. L'Harmonie Universelle. Paris: S. Cramoisy, 1636. Disponível em: https://gallica.bnf.fr/ark:/12148/bpt6k5471093v?rk=42918;4. Acesso em: 10/09/2021.

MOUREY, Marie-Thérèse. L'art du ballet de cour au XVIIe siècle: poétique de l'image animée. Colloque École Doctorale IV - Université Paris IV-Sorbonne, $11-13$ junho 2009. 
NEGRI, Cesare. Nuove inventioni di balli. Milão: Girolamo Bordono, 1604. Disponível em: https://gallica.bnf.fr/ark:/12148/bpt6k135195k?rk=21459;2. Acesso em: 10/09/2021.

NEVILE, Jennifer. The eloquent body: dance and humanistic culture in fifteenth-century Italy. Bloomington: Indiana University Press, 2004.

NICOT, Jean. Dictionaire François-latin. Paris: Iaques du Puys, 1584. Disponível em: https://gallica.bnf.fr/ark:/12148/bpt6k6153020h?rk=64378;0. Acesso em: $10 / 09 / 2021$.

NOCILLI, Cecilia. El manuscrito de Cervera: musica y danza palaciega catalana del siglo XV. Barcelona: Amalgama Edicions, 2013.

NORDERA, Marina. La réduction de la danse en art (xvexviiie siècle) In: DUBOURG, Pascal e VÉRIN, Hélène (dir.). Réduire en art: La technologie de la Renaissance aux Lumières. Paris: Éditions de la Maison des sciences de l'homme, 2008. P. 269-291.

NORDERA, Marina. Savoir danser, apprendre à écrire (xvexvie siècle). In: HILAIRE-PEREZ, Liliane; NEGRE, Valerie; SPICQ, Delphine; VERMEIR, Koen (DIR.). Le livre technique avant le xxe siècle: À l'échelle du monde. Paris: CNRS Éditions, 2017. P. 95-108. Disponível em: <http://books.openedition.org/editionscnrs/27694>. Acesso em: 29/04/2021.

PAQUOT, Marcel. La manière de composer les ballets de cour d'après les premiers théoriciens français. Cahiers de l'Association internationale des études françaises, n.9, pp. 183-197, 1957.

ROUCHER, Eugénia. Saint-Hubert. In: LE MOAL, Philippe (dir.). Dictionnaire de la danse. Paris: Larousse, 1999. p. 380-381.

SAINT-HUBERT, Nicolas de. La manière de composer et faire réussir les Ballets (1641). Genebra: Éditions Minkoff, 1993.

YATES, Frances. The French Academies of the sixteenth century. Londres: Warburg Institute, University of London, 1947.

Clara Rodrigues Couto é graduada em História pela Universidade Federal de Uberlândia (UFU) e mestre em História Social pela FFLCH-USP. Desenvolveu dissertação sobre os balés de corte como cerimoniais políticos na França do século XVII (FAPESP) e traduziu o tratado de balé de Nicolas de Saint-Hubert (1641). É integrante dos grupos de pesquisa Sentidos do Barroco PUC-SP/CNPq, Grupo 
de Estudos em História Ibérica Moderna (GEHIM-USP) e bailarinapesquisadora do grupo Passos do Barroco.

ORCID: https://orcid.org/0000-0003-0993-3483

E-mail: claracouto87@gmail.com

Este texto inédito também se encontra publicado em inglês neste número do periódico.

Recebido em 30 de abril de 2021 Aceito em 11 de agosto de 2021

Editores responsáveis: Arnaldo de Siqueira Junior

Cassia Navas

Gilberto Icle

Henrique Rochelle

Este é um artigo de acesso aberto distribuído sob os termos de uma Licença Creative Commons Atribuição 4.0 Internacional. Disponível em: <http://creativecom mons.org/licenses/by/4.0>. 